\title{
Exploration of Microbial Diversity of Himalaya Region for Gold Nanoparticles Synthesizing Bacteria
}

\author{
Rajni Kant Thakur*, Poonam Shirkot and Ambika Verma \\ Department of Biotechnology, Dr. Y.S Parmar University of Horticulture and Forestry, India \\ *Corresponding author
}

\section{A B S T R A C T}

\begin{tabular}{|c|c|}
\hline Keywords & bacterial isolates were isolated from the samples using nutrient agar $\mathrm{m}$ \\
\hline $\begin{array}{l}\text { Nanoparticles, } \\
\text { Transmission } \\
\text { electron } \\
\text { microscope. }\end{array}$ & $\begin{array}{l}\text { isolates were screened individually for their ability to synthesize gold nanoparticles and } \\
\text { only } 38 \text { bacterial isolates, from goldmine were shown to possess gold nanoparticles } \\
\text { synthesizing activity. Formation of gold nanoparticles was confirmed by colour change of } \\
\text { the solution from yellow to purple/red wine colour. An indigenous bacterial isolate capable }\end{array}$ \\
\hline Article Info & 2, based on its morphology and analysis of its $16 \mathrm{~S}$ rDNA gene sequencing. After 6-12 hrs \\
\hline $\begin{array}{l}\text { Accepted: } \\
21 \text { June } 2017 \\
\text { Available Online: } \\
10 \text { August } 2017\end{array}$ & $\begin{array}{l}\text { of } 1 \text { and found to be of } 45 \mathrm{~nm} \text { size. Gold nanoparticles were characterized through FTIR, } \\
\text { transmission electron microscope with the size range of } 40-45 \mathrm{~nm} \text {. The process of } \\
\text { synthesis of nanoparticles using an indigenous bacterial isolate from gold mine pebbles } \\
\text { sample has been reported in this study, leading to the development of an easy bioprocess }\end{array}$ \\
\hline & $\begin{array}{l}\text { for synthesis of GNPs with many potential applications. The use of gold compounds and } \\
\text { gold nanoparticles, with respect to their potential therapeutic applications such as anti- } \\
\text { angiogenesis as anti-malarial agent, anti-arthritic agent, drug delivery, gene transfer, } \\
\text { cancer nanotechnology, drug delivery applications, and its optical properties for cancer } \\
\text { diagnosis and photo thermal therapy and biosensors, bio imaging, antimicrobial activity, } \\
\text { food preservation. }\end{array}$ \\
\hline
\end{tabular}

The isolation of gold nanoparticles synthesizing bacteria from natural sources and their identification are very important in terms of discovering new industrial products. Keeping in view, local goldmine at Khaltunala and four hot water springs of Himachal Pradesh were selected as a source for new gold nanoparticles synthesizing bacteria. Therefore, aim of the present study was the isolation and characterization of gold nanoparticles synthesizing bacteria from these sites for synthesis of gold nanoparticles. Eighty five bacterial isolates were isolated from the samples using nutrient agar medium. All the bacterial isolates were studied for various morphological characters. Eighty five bacterial isolates were screened individually for their ability to synthesize gold nanoparticles and only 38 bacterial isolates, from goldmine were shown to possess gold nanoparticles synthesizing activity. Formation of gold nanoparticles was confirmed by colour change of the solution from yellow to purple/red wine colour. An indigenous bacterial isolate capable 2, gold nanoparticles synhesis was isolate and identifed as a Bacillus licheniformis GPIof incubation, monodisperse gold nanoparticles were, obtained. Which were characterized and found to be of $45 \mathrm{~nm}$ size. Gold nanoparticles were characterized through FTIR, transmission electron microscope with the size range of $40-45 \mathrm{~nm}$. The process of synthesis of nanoparticles using an indigenous bacterial isolate from gold mine pebbles sample has been reported in this study, leading to the development of an easy bioprocess gold nanoparticles, with respect to their potential therapeutic applications such as antiangiogenesis as anti-malarial agent, anti-arthritic agent, drug delivery, gene transfer, cancer nanotechnology, drug delivery applications, and its optical properties for cancer diagnosis and photo thermal therapy and biosensors, bio imaging, antimicrobial activity,

\section{Introduction}

Microbial diversity of the Himalaya region is mostly unexplored towards the gold nanoparticles synthesis by bacteria so far. Microbes are primitive organisms which inhabit the earth since origin of life on earth, because of their versatile adaptability they not only survive during millions of the years but they are highly significant in maintaining ecological balance on earth. Explorations of Himalaya region for beneficial bacterial species can potentially provide us novel microbes with newer applications, which may be highly efficient and significant to biotechnology, microbial industry. So in order 
to explore the microbial diversity of mid region of Himalaya, we have conducted the survey of different sites like Manikaran, Kasol, Kalath, Vashisht hot water springs, Rhontang, gold mine Khaltunala. The microbial world is vast, with $10^{30}$ organisms present on the earth, diverse and can only be observed through relatively tiny samples at discrete points in space and time. Biodiversity is related to the number of species, or species richness, along with the richness of activity each species undergoes during its existence through events in the life of its members, plus the non phenotypic expression of its genome. Thus, to study microbial biodiversity, it is necessary to understand interactions between and among species in a given habitat. According to Erwin, 'how these species are grouped as a living unit' in a given ecological unit, is a task that is heroically difficult to complete for microorganisms, without a massive, globally coordinated program of action. The diversity of microbial communities and their ecologic and metabolic functions are being explored across a great range of natural environments: in soils (Whitman et al., 1998; Atlas and Bartha, 1993; Redwood, 1998), air (Fierer et al., 2007) and seas (Schloss and Handelsman, 2006; Roesch et al., 2007; Brodie et al., 2007), on plants (Alonso and Gasol, 2007) and in animals (Frias-Lopez et al., 2008; Sogin et al., 2006) and in extreme environments such as the arctic (Stevens and Ulloa, 2008), deep-sea vents (Fang et al., 2005), uranium-contaminated soil (Michalke et al., 2008), and waste-water treatment discharge (Sharma et al., 2009). In recognition of the role marine microbes play in the biogeochemical processes that are critical to life in all environments on Earth including carbon and nitrogen cycling, the International Census of Marine Microbes. Microbial communities are central to health, sustainable cities, agriculture, and most of the planet's geochemical cycles. Prokaryote communities are also reservoirs for the discovery of new drugs and metabolic processes. As with any reservoir, its size is important. In the world of microbial ecology, we need theory very badly. Almost any consequential microbial community will have $10^{10}$ to $10^{17}$ bacteria that could compose more than $10^{7}$ differing taxonomic groups and countless functional groups. It seems remarkable that we should even contemplate trying to understand such vast systems without recourse to some form of theory. It is now well recognized that, for many decades, microbiologists had grossly underestimated microbial diversity levels by relying on cultivation-based techniques, which capture only a select few microbial taxa capable of growing rapidly under artificial laboratory conditions. Likewise, with few obvious morphological differences delineating most microbial taxa, direct microscopic analyses of environmental samples are of little use for quantifying microbial diversity. By using high-throughput nucleic-acid-based analyses of microbial communities, researchers have gained new appreciation for the breadth and dynamics of microbial diversity in specific habitats, the spatial and temporal variability in the levels of microbial diversity, and the factors driving this variability. Bioprospecting is novel concept for exploiting locally available microbial species in ecosystem. Microbial species can be exploited towards biosynthesis of gold nanoparticles and involve simple experimental conditions such as incubation time, temperature, $\mathrm{pH}$ and wavelength (Gade et al., 2008). Microbial diversity is an excellent resource for biotechnological innovations as biomaterials of nanometer dimension form the basis of life. Diversity of life especially microorganisms is being used from several decades as ecofriendly nanofactories for the biosynthesis and production of many useful products such as enzymes, therapeutic proteins, life saving vaccines and now various types, of metal 
nanoparticles including gold nanoparticles (Riddin et al., 2006; Sharma et al., 2012). Gold in different forms, has been used in medicine throughout the history of civilization. The use of gold compounds and gold nanoparticles, with respect to their potential therapeutic applications such as antiangiogenesis (Mukherjee et al., 2005), as antimalarial agent (Navarro et al., 1997) and antiarthritic agent (Tsai et al., 2007)drug delivery (Khan et al., 2014), gene transfer (Shomura et al., 2011), cancer nanotechnology (Cail et al., 2008), drug delivery applications (Ghosh et $a l ., 2008)$, and its optical properties for cancer diagnosis and photo thermal therapy and biosensors (Amanda et al., 2005), bio imaging (Mohammed et al., 2009), antimicrobial activity (Mohammed et al., 2010) food preservation (Mohammed et al., 2009).

Generally nanoparticles are synthesized through various physical and chemical methods but with poor morphology and these procedures are very expensive and prove to be toxic to environment because of use of toxic chemicals and high temperature used for synthesis process (Rai et al., 2008; Birla et al., 2009). Biological method provides a wide range of resources for the synthesis of nanoparticles. The rate of reduction of metal nanoparticles using biological agents is found to be much faster and also at ambient temperature (Gade et al., 2008; Mukherji et al., 2008). Shape and size of nanoparticles can be altered through changing in $\mathrm{pH}$, temperature of reaction mixture (Gericke, 2006). Microorganisms secrete enormous amount of enzymes, which are capable of hydrolyzing metals and thus bring about enzymatic reduction of metal into metal ions (Rai et al., 2009). Enzyme nitrate reductase has been found to be responsible for the synthesis of nanoparticles in case of fungi (Kumar et al., 2007; Kumar et al., 2007). Thus biosynthesis of gold nanoparticles using microbes is less labour intensive, low cost, non toxic and is more ecofriendly. In case of bacteria Lactobacillus species during the initial stages of synthesis of nanoparticles, nucleation of clusters of metal ions take place and hence there is electrostatic interaction between the bacterial cell and metal cluster which leads to formation of nanoclusters at the end, smaller sized nanoclusters get diffused through bacterial cell wall (Nair and Pradeep, 2002). The mechanism of extracellular synthesis of nanoparticles using microbes is basically found to be nitrate reductase mediated synthesis (Duran et al., 2005).

The cell wall of the microorganisms plays a major role in the intracellular synthesis of nanoparticles. The cell wall being negatively charged interacts electrostatically with the positively charged metal ions. The enzymes present within the cell wall bioreduce the metal ions to nanoparticles, and finally the smaller sized nanoparticles get diffused of through the cell wall.

\section{Materials and Methods}

\section{Survey and selection of the sites}

A survey was conducted for selection of various sites of goldmines and hot water springs from different districts of Himachal Pradesh. Goldmine Khaltunala which is three $\mathrm{km}$ far from Nauni village in district Solan and four hot water springs viz., Manikaran, Vashisht, Kasol and Kalath located in Kullu district of Himachal Pradesh were surveyed and selected. Manikaran is one of hottest water springs of Himachal Pradesh, which is $45 \mathrm{~km}$ from Kullu, Kasol is $15 \mathrm{~km}$ from Manikaran, lies in the Parvati valley of Kullu district. Kalath is $10 \mathrm{~km}$ from Manali and lies in lap of Beas River. Vashisht is $6 \mathrm{~km}$ from Manali, located well above the river Beas was surveyed and selected. The geographical locations of these sites along with their altitudes $(\mathrm{m})$ have been described in table 1 . 


\section{Isolation and identification of gold nanoparticles and bacteria}

A survey was conducted for selection of various sites of goldmines Khaltunala, in Solan, Kullu districts of Himachal Pradesh. Eighty seven samples in form of water, soil, biofilm, pebbles, roof topping/stalagamite and rock matting were collected from gold mine sites and four hot water springs viz., Manikaran, Vashisht, Kasol and Kalath of Himachal Pradesh. (Map 1, Figure 1) All these samples were kept at $4^{\circ} \mathrm{C}$ in refrigerator in laboratory till further experimentation. Three different culture media were investigated for isolation of gold nanoparticles synthesizing bacterial isolates viz., Nutrient agar medium, Eosin methylene blue agar medium and Luria bertani medium. One gram soil, Pebbles, stalagmite $/ 1.0 \mathrm{ml}$ water, biofilm samples collected from sampling sites were dissolved in $9.0 \mathrm{ml}$ of sterile water and serial dilution technique was used for isolation of bacterial isolates. The plates were incubated at $37^{\circ} \mathrm{C}$ for $24-48 \mathrm{hrs}$ for bacterial growth. Turbid cultures were streaked on plates of solidified growth medium. Individual colonies were restreaked repeatedly, and the axenic cultures thus obtained were stored at $4^{\circ} \mathrm{C}$.

\section{Morphological characterization}

All the bacterial isolates obtained in previous step were further studied for various morphological characters. Various morphological descriptors of colour, size, optical property and elevation of the colonies and various microscopic characteristics studied were gram reaction, shape, arrangement and spore formation.

\section{Quantitative screening of bacterial isolates for gold nanoparticles synthesis ability}

Assessment of all eighty five bacterial isolates for their ability to synthesize gold nanoparticles was carried out. One percent concentration of the inoculum (overnight culture) of each bacterial isolate was inoculated into the $50 \mathrm{ml}$ nutrient broth followed by incubation at $37^{\circ} \mathrm{C}$ for $24-48 \mathrm{hrs}$ at $150 \mathrm{rpm}$. Supernatant of each bacterial culture was collected by centrifugation at $8500 \mathrm{rpm}$ for 15 minutes at $4^{\circ} \mathrm{C}$ to study extracellular synthesis of gold nanoparticles. Ten $\mathrm{ml}$ of each supernatant was mixed with $10 \mathrm{ml}$ of $1 \mathrm{mM}$ solution of $\mathrm{HAuCl}_{4}$ and incubated at $37^{\circ} \mathrm{C}$ for $240 \mathrm{hrs}$. Formation of gold nanoparticles was studied 0-240 hrs, with an interval of $12 \mathrm{hrs}$ and confirmed by colour change of the solution from light yellow to red wine/purple colour. This formation of gold nanoparticles was also confirmed by the Spectrophotometer (Spectronic 20, Milton Roy Company) at two different wavelengths of 540 and $560 \mathrm{~nm}$.

\section{Biochemical characterization and molecular characterization}

Various biochemical characters were investigated using standard assays. Genomic DNA extraction Mini kit (Real Genomics). Presence of DNA and its quality was checked using $1.0 \%$ agarose gel and then was viewed by UV trans-illuminator. After visual confirmation of DNA bands in the gel, photograph of the same gel were taken by gel documentation apparatus, Alphalmager ${ }^{\mathrm{TM}}$ (Alpha Infotech Corporation, USA). The DNA of GBI-3 was selectively amplified using PCR technology. Universal primers B27F (5'-AGAGTTTGATCCTGGCTCAG3'U1492R) and (5'GGTTACCTTGTTACGACTT-3') for $16 \mathrm{~S}$ rrna gene were used for the experiment. The eluted and purified DNA of GBI-3 was sequenced. The sequences have been submitted to NCBI with accession number KP 219453. To gain insight of the evolutionary pattern, phylogenetic tree was constructed using MEGA 5.0 bioinformatics tool. Neighbour-Joining (NJ) technique of 
mathematical averages (UPGMA) was used. Nanoparticles obtained were analyzed using various techniques such as, Fourier transform infrared spectroscopy (FTIR and Transmission electron microscope.

Optimization of culture conditions for maximum gold nanoparticles synthesis by selected bacterial isolate

The culture conditions for useful and prized microorganisms are generally optimized to obtain higher yields of their useful products. In the present study the best bacterial isolate was selected by quantitative assay of gold nanoparticles synthesizing activity. The bacterial isolate depicting maximum gold nanoparticles synthesis activity was selected and further investigated to study the effect of different factors such as incubation time, temperature, $\mathrm{pH}$ and wavelength on gold nanoparticles synthesis.

\section{Effect of incubation time}

Effects of different incubation times for maximum gold nanoparticles synthesis were investigated ranging from $0-72 \mathrm{hrs}$, and the optimum incubation time leading to maximum gold nanoparticles production of gold nanoparticles was selected.

\section{Effect of incubation temperature}

Effect of incubation temperature for maximum gold nanoparticles synthesis was studied at a temperature range of $10-50^{\circ} \mathrm{C}$ using nutrient broth and the optimum temperature leading to maximum gold nanoparticles production of gold nanoparticles was selected.

\section{Effect of pH}

To find optimum $\mathrm{pH}$ for maximum gold nanoparticles synthesis by selected bacterial isolate, a $\mathrm{pH}$ range of 5.0-7.5 was examined using nutrient broth medium at an optimum temperature and optimum time. The best condition leading to maximum gold nanoparticles production of gold nanoparticles was selected.

\section{Effect of wavelength}

Effects of different wavelength for the maximum values of gold nanoparticle synthesis were investigated ranging from 400$650 \mathrm{~nm}$. The optimum wavelength leading to maximum readings of gold nanoparticles synthesis was selected.

\section{In vitro synthesis of gold nanoparticles by Bacillus licheinformis GPI-2}

\section{Fourier transform infrared spectroscopy}

Microcup was washed with $100 \%$ absolute ethanol. 10 ul sample was filled in a $2 \mathrm{~mm}$ internal diameter microcup and loaded onto the FTIR set at $26^{\circ} \mathrm{C} \pm 1^{\circ} \mathrm{C}$. The samples were scanned in the range of 4,000 to $400 \mathrm{~cm}^{-1}$ using a Fourier transform infrared spectrometer (Thermo Nicolet Model 6700, Waltham, MA, USA). The spectral data obtained were compared with the reference chart to identify the functional groups present in the sample.

\section{Transmission electron microscope}

TEM studies were carried out using Jeol 2100 microscope operating at $120 \mathrm{kV}$ accelerating voltage. Samples were prepared by placing a drop of in vitro gold nanoparticles solutions on carbon-coated TEM grids. The films on the TEM grids were allowed to dry for $5 \mathrm{~min}$ at room temperature before analysis.

\section{Results and Discussion}

Isolation of gold nanoparticle synthesizing bacteria was carried out from samples using nutrient agar medium at $37^{\circ} \mathrm{C}$. All the 
samples were inoculated in $150 \mathrm{ml}$ flasks containing $50 \mathrm{ml}$ nutrient broth and incubated at $37^{\circ} \mathrm{C}$ at $50 \mathrm{rpm}$ for $24 \mathrm{hrs}$. Turbid cultures were streaked on plates of solidified nutrient agar medium (1.5\% agar). Individual colonies were restreaked repeatedly and the purified colonies were stored at $4^{\circ} \mathrm{C}$ in refrigerator till further processing/use. A total of eighty five bacterial isolates were isolated from eighty seven samples. From goldmine a total of 43 bacterial isolates were obtained and rest 42 bacterial isolates were obtained from sample of various hot water springs. Different colony morphotypes have been observed. On the basis of colour, $10.5 \%$ morphotypes were found creamish white in colour, rests of them were found white in colour. On the basis of shape $49 \%$ isolates showed circular morphotypes, $51 \%$ were irregular in shape. On the basis of opacity only $15.3 \%$ morphotypes possessed non- opaque colony and rest were opaque.

\section{Quantitative screening of bacterial isolates for gold nanoparticles synthesis ability}

Eighty five bacterial isolates were screened individually for their ability to synthesize gold nanoparticles. One percent concentration of inoculum (overnight culture) was inoculated into the nutrient broth for gold nanoparticles synthesis followed by incubation at $37^{\circ} \mathrm{C}$ for $24 \mathrm{hrs}$ at $50 \mathrm{rpm}$. The supernatant was collected by centrifugation at $8500 \mathrm{rpm}, 4^{\circ} \mathrm{C}$ for 15 mins to investigate extracellular synthesis of gold nanoparticles using the supernatant. $10 \mathrm{ml}$ of supernatant was mixed in $10 \mathrm{ml}$ of $1 \mathrm{mM}$ solution of gold chloride $\left(\mathrm{HAuCL}_{4}\right)$, prepared with double distilled water and incubated at $37^{\circ} \mathrm{C}$ for 36 hrs.

Formation of gold nanoparticles was confirmed by colour change of the solution from yellow to red wine/purple colour (Figure-2). This formation of gold nanoparticles was also confirmed by the Spectrophotometer (Spectronic 20, Milton Roy Company) at two different wavelengths of 540 and $560 \mathrm{~nm}$. Out of the total of 85 bacterial isolates, it has been observed that only 38 bacterial isolates, of a total 43 isolated from goldmine have been possess to produce gold nanoparticles synthesizing activity and none of 42 bacterial isolates obtained from hot water springs have been shown to possess gold nanoparticles synthesizing activity. Out of thirty eight gold nanoparticles synthesizing isolates only eleven bacterial isolates has been selected for further studies on the basis of maximum gold nanoparticles synthesis viz., GBI-1, GBI-2, GBI-3, GYI-4, GYI-5, GYI-10, GYI-11, GPI2, GPI-3, GPI-5 and GPI-6.

\section{Statistical analysis of data}

On the basis of data analysis using CRD and OPSTAT software package GBI-3 bacterial isolate, the maximum producer of gold nanoparticles possessed the maximum mean of 0.940 at $540 \mathrm{~nm}$, which was found to be higher than rest of the bacterial isolates followed by bacterial isolates GPI-2 and GBI1 , with mean values of 0.880 and 0.870 respectively at $540 \mathrm{~nm}$ (Table-2).

Irrespective of bacterial isolates, GBI-3 was giving maximum O.D value at $36 \mathrm{hrs}$ which was found to be the higher then all other isolates. In the interaction effect of maximum producer of gold nanoparticles and time interval the maximum concentration of gold nanoparticles was recorded for GBI-3 after 36 hrs which was statistically at par with treatment combination GPI-2 and GBI-1 at 36 hrs. Again, GBI-3 isolate was the maximum producer of gold nanoparticles with mean value of 0.960 at $560 \mathrm{~nm}$, which was found to be higher than all other isolates followed by GBI-1 and GPI-2, with mean values of 0.900 and 0.880 respectively at $560 \mathrm{~nm}$ (Table-3). 


\section{Biochemical and molecular characterization}

Pure colonies isolated from the different samples were characterized for their morphological and physiological characteristics by various biochemical tests using the Bergey's Manual of Determinative Bacteriology (Holt et al., 1994). The screened strain is an aerobic, gram positive, rod shaped with round colonies in shape, $2 \mathrm{~mm}$ in diameter with undulated margin, opaque with rough surface. GPI-2 bacterial isolate tested positive for arginine dihydrolase, hydrolysis of esculin, beta galactosidase, phenyl alanine deaminated, degradation of tyrosine acid production from glycerol, salicine, starch, glycogen, lactose, D mannose, maltose, ribose, Sorbitol, sucrose, and found negative for lysine decarboxylase, ornithine decarboxylase, tryptophan, deaminase, hydrolysis of urea, acid production from $\mathrm{D}$ and L fucose, methyl beta xyloside, D arabinose, $\mathrm{D}$ and $\mathrm{L}$ arabitol, adonitol, sorbose, lyxose.

Molecular characterization was carried out using 16S r DNA-PCR technology. Total genomic DNA of the GPI-2 bacterial isolate was extracted successfully using genomic DNA extraction Mini kit (Real Genomics) and was selectively amplified with universal primers for 16S rrna gene followed by agarose gel electrophoresis leading to a single clear band. This was eluted, purified and sequenced. The sequence was submitted to NCBI with accession number Genbank KP219455. BLASTn analysis depicted homology of GPI-2 bacterial isolate with other Bacillus species. To gain insight of evolutionary pattern, phylogenetic tree was constructed using MEGA 5.0 bioinformatic tool (Tamura et al., 2011). The bootstrap analysis values identified the bacterial isolate GPI-2 as Bacillus licheniformis GPI-2 (Figure 3 ), Multiple sequence alignment of query nucleotide sequence of maximum gold nanoparticles synthesizing indigenous Bacillus licheniformis strain GPI-2 was performed with that of the selected nucleotide sequences using Clustal W program and pairwise percent similarity score of these selected fifteen nucleotide sequences obtained from NCBI database with test isolate GPI-2 from goldmine, elucidates that sequence-1. Bacillus licheniformis strainGPI-2 showed maximum similarity score of $99 \%$ with Bacillus licheniformis strain NCDO 1772 16S ribosomal RNA gene partial sequence.

In vitro synthesis of gold nanoparticles by indigenous Bacillus licheniformis strainGPI-2

Extracellular biosynthesis of gold nanoparticles was carried out using supernatant of Bacillus licheniformis strainGPI-2, treated with $1 \mathrm{mM}$ gold chloride solution and incubated at $37^{\circ} \mathrm{C}$ for a time period of 0-240 hrs. Biosynthesis absorption spectra of gold nanoparticles which was indicated by colour change of solution from yellow to red wine (Figure 2) and was further confirmed spectrophotometrically. UV-VIS absorption spectra and the time of incubation course and increase in formation of gold nanoparticles took place up to $36 \mathrm{hrs}$ and remained stable up to $48 \mathrm{hrs}$ and then the values declined up to 240 hrs. Gold nanoparticles formation clearly revealed the gold nanoparticles formation initiated after 6 hrs and studies at two different wavelengths of $540 \mathrm{~nm}$ and $560 \mathrm{~nm}$ (Figure $4 \mathrm{a}$ and $4 \mathrm{~b}$ ). On the basis of statistical analysis of data obtained at two wavelengths $540 \mathrm{~nm}$ and 560 $\mathrm{nm}$, it was observed that optical density values were higher at $560 \mathrm{~nm}$ (Tables 2 and 3) and gold nanoparticles also showed more stability at 36-48 hrs, thus $560 \mathrm{~nm}$ wavelength was found superior over $540 \mathrm{~nm}$ and was selected for further experiments. 
Optimization of culture conditions for maximum gold nanoparticles synthesis by Bacillus licheniformis strain GPI-2

The bacterial isolate Bacillus licheniformis GPI-2depicting maximum gold nanoparticles synthesis activity was further optimized to study the effect of different factors such as incubation time, temperature, $\mathrm{pH}$ and wavelength on gold nanoparticles synthesis. Effect of $\mathrm{pH}$ on biosynthesis of gold nanoparticles by Bacillus licheniformis GPI2bacterial supernatant of was studied for 0-72 hrs using $1 \mathrm{mM}$ gold chloride solution at a $\mathrm{pH}$ range of 5.0, 6.0, 6.8, 7.5, 8.0 (Fig. 5a) and it was observed that maximum gold nanoparticles took place at $\mathrm{pH}$ : 6.8. Thus $\mathrm{pH}$ has been found to be an important parameter affecting gold nanoparticles synthesis. Variation in $\mathrm{pH}$ during exposure to gold ions had an impact on the size, shape and number of particles produced per cell (Kaithresan et al., 2009). Gold nanoparticles formed at $\mathrm{pH}$ 6.8 were predominantly triangles, spherical, hexagons, circular in shape. Whenever $\mathrm{pH}$ increases, more competition occurs between protons and metal ions for negatively charged binding sites (Sintubin et al., 2009). Effects of different incubation times for maximum gold nanoparticles synthesis were investigated from 0-72 hrs. The optimum incubation time of $36 \mathrm{hrs}$, leading to maximum gold nanoparticles production was observed (Figure 5b). Effect of incubation temperature for maximum gold nanoparticles synthesis was studied at a temperature range of $10-50^{\circ} \mathrm{C}$ +using nutrient broth and optimum temperature of $37^{\circ} \mathrm{C}$ leading to maximum gold nanoparticles synthesis was observed (Figure 5c). It has also been reported that incubation time for maximum gold nanoparticles formation ranges from 30 to $37^{\circ}$ C (Lengke et al., 2006). Effect of different wavelengths for the maximum optical density values of gold nanoparticles synthesis was investigated in the range of 400-650 $\mathrm{nm}$ and an optimum wavelength of $560 \mathrm{~nm}$ was found to be leading to maximum values of optical density of gold nanoparticles synthesis (Figure 5d).

Characterization of in vitro synthesis of nanoparticles by Bacillus licheniformis strain GPI-2

FTIR measurements were carried out to identify the possible biomolecules protein responsible for the capping and efficient stabilization of the gold nanoparticles synthesized by Bacillus licheniformis GPI-2. FTIR spectrogram has shown presence of four peaks 3280.18, 2380.99, 2109.12 and 1636.32 (Figure 6). The FTIR spectra reveal the presence of different functional groups. Wavenumber between 3235 and $3280 \mathrm{~cm}^{-1}$ Indicates for hydrogen bond lengths between 2.69 to $2.85 \mathrm{~A}^{\mathrm{o}}$. Alkynes $\mathrm{C}-\mathrm{C}$ triple bond stretch is found at $2109 \mathrm{~cm}^{-1}$. Peak at 1636 $\mathrm{cm}^{-1}$ corresponds to the $\mathrm{N}-\mathrm{H}$ bend of primary amines due to carbonyl stretch. Amide 1 is most intensive absorption band in protein. It is primarily governed by the stretching vibration of the $\mathrm{C}=\mathrm{O}(70-80 \%)$ and $\mathrm{CN}$ stretching groups (10-20\%) frequency 1600$1700 \mathrm{~cm}^{-1}$. In the amide I region (1700-1600 $\mathrm{cm}^{-1}$ ), each type of secondary structure gives rise to a somewhat different $\mathrm{C}=\mathrm{O}$ stretching frequency due to unique molecular geometry and hydrogen bonding pattern. N-H Stretch of primary and secondary amines, amides. Amide $\mathrm{A}$ is with more than $95 \%$ due to $\mathrm{N}-\mathrm{H}$ stretching vibration. This mode of vibration does not depend on the backbone conformation but is very sensitive to the strength of a hydrogen bond. Peak maximum around $1650 \mathrm{~cm}^{-1}$ corresponds to proteins alpha helical structure. Half width of alpha helix band depends upon on the stability of the helix. When half width of about $15 \mathrm{~cm}^{-1}$ then we have more stability of helix and transition free energy of more than 300 $\mathrm{cal} / \mathrm{ml}$. 
Table.1 Geographical location of selected sites

\begin{tabular}{|c|c|c|c|c|}
\hline Sr. No. & Sites & Districts & Sample codes & Altitude \\
\hline \multirow[t]{10}{*}{1.} & \multirow{10}{*}{$\begin{array}{l}\text { Goldmine } \\
\text { (Biofilm) }\end{array}$} & \multirow{10}{*}{ Solan } & GBI-1 & \\
\hline & & & GBI-2 & \multirow{42}{*}{$1000 \mathrm{~m}$} \\
\hline & & & GBI-3 & \\
\hline & & & GBI-4 & \\
\hline & & & GBI-5 & \\
\hline & & & GBI-6 & \\
\hline & & & GBI-7 & \\
\hline & & & GBI-8 & \\
\hline & & & GBI-9 & \\
\hline & & & GBI-10 & \\
\hline \multirow[t]{11}{*}{2.} & \multirow{11}{*}{$\begin{array}{l}\text { Goldmine } \\
\text { (Roof } \\
\text { topping) }\end{array}$} & \multirow[t]{11}{*}{ Solan } & GRI-1 & \\
\hline & & & GRI-2 & \\
\hline & & & GRI-3 & \\
\hline & & & GRI-4 & \\
\hline & & & GRI-5 & \\
\hline & & & GRI-6 & \\
\hline & & & GRI-7 & \\
\hline & & & GRI-8 & \\
\hline & & & GRI-9 & \\
\hline & & & GRI-10 & \\
\hline & & & GRI-11 & \\
\hline \multirow[t]{12}{*}{3.} & \multirow{12}{*}{$\begin{array}{l}\text { Goldmine } \\
\text { (Yellow soil) }\end{array}$} & \multirow[t]{12}{*}{ Solan } & GYI-1 & \\
\hline & & & GYI-2 & \\
\hline & & & GYI-3 & \\
\hline & & & GYI-4 & \\
\hline & & & GYI-5 & \\
\hline & & & GYI-6 & \\
\hline & & & GYI-7 & \\
\hline & & & GYI-8 & \\
\hline & & & GYI-9 & \\
\hline & & & GYI-10 & \\
\hline & & & GYI-11 & \\
\hline & & & GYI-12 & \\
\hline \multirow[t]{10}{*}{4.} & \multirow{10}{*}{$\begin{array}{l}\text { Goldmine } \\
\text { (Pebbles) }\end{array}$} & \multirow[t]{10}{*}{ Solan } & GPI-1 & \\
\hline & & & GPI-2 & \\
\hline & & & GPI-3 & \\
\hline & & & GPI-4 & \\
\hline & & & GPI-5 & \\
\hline & & & GPI-6 & \\
\hline & & & GPI-7 & \\
\hline & & & GPI-8 & \\
\hline & & & GPI-9 & \\
\hline & & & GPI-10 & \\
\hline \multirow[t]{3}{*}{5.} & \multirow{3}{*}{$\begin{array}{l}\text { Manikaran } \\
(\mathrm{MS} 1)\end{array}$} & \multirow[t]{3}{*}{ Kullu } & MS1I-1 & \multirow[t]{3}{*}{$1735 \mathrm{~m}$} \\
\hline & & & MS1I-2 & \\
\hline & & & MS1I-3 & \\
\hline
\end{tabular}




\begin{tabular}{|c|c|c|c|c|}
\hline & & & MS1I-4 & \\
\hline & & & MS1I-5 & \\
\hline & & & MS1I-6 & \\
\hline & & & MS1I-7 & \\
\hline 6. & Manikaran & Kullu & MS2I-1 & \\
\hline & (MS2) & & MS2I-2 & \\
\hline & & & MS2I-3 & \\
\hline & & & MS2I-4 & \\
\hline 7. & Manikaran & Kullu & MS3I-1 & \\
\hline & (MS3) & & MS3I-2 & \\
\hline & & & MS3I-3 & \\
\hline 8. & Manikaran & Kullu & MS4I-1 & \\
\hline & (MS4) & & MS4I-2 & \\
\hline & & & MS4I-3 & \\
\hline 9. & Vashisht & Kullu & VS1I-1 & \\
\hline & (VS1) & & VS1I-2 & \\
\hline & & & VS1I-3 & \\
\hline & & & VS1I-4 & \\
\hline 10. & Vashisht & Kullu & VS2I-1 & $2050 \mathrm{~m}$ \\
\hline & (VS2) & & VS2I-2 & $2050 \mathrm{~m}$ \\
\hline & & & VS2I-3 & \\
\hline & & & VS2I-4 & \\
\hline & & & VS2I-5 & \\
\hline & & & VS2I-6 & \\
\hline 11. & Kalath & Kullu & KaS1I-1 & \\
\hline & (KaS1) & & KaS1I-2 & \\
\hline & & & KaS1I-3 & \\
\hline & & & KaS1I-4 & \\
\hline 12. & Kalath & Kullu & KaS2I-1 & $2050 \mathrm{~m}$ \\
\hline & $(\mathrm{KaS} 2)$ & & KaS2I-2 & \\
\hline & & & KaS2I-3 & \\
\hline & & & KaS2I-4 & \\
\hline 13. & Kasol & Kullu & KS1I-1 & \\
\hline & (KS1) & & KS1I-2 & \\
\hline & & & KS1I-3 & \\
\hline & & & KS1I-4 & \\
\hline & & & KS1I-5 & $1640 \mathrm{~m}$ \\
\hline & & & KS1I-6 & \\
\hline & & & KS1I-7 & \\
\hline 14. & Kasol & Kullu & KS2I-1 & \\
\hline & (KS2) & & KS2I-2 & \\
\hline
\end{tabular}


Table.2 Statistical analysis of effect of time (hrs.) on gold nanoparticles synthesis at $540 \mathrm{~nm}$ O.D

\begin{tabular}{|c|c|c|c|c|c|c|c|c|c|c|c|}
$\begin{array}{r}\text { Time in } \\
\begin{array}{c}\text { (hrs) } \\
\text { Isolates }\end{array}\end{array}$ & $\mathbf{0}$ & $\mathbf{1 2}$ & $\mathbf{2 4}$ & $\mathbf{3 6}$ & $\mathbf{4 8}$ & $\mathbf{6 0}$ & $\mathbf{7 2}$ & $\mathbf{8 4}$ & $\mathbf{9 6}$ & $\mathbf{1 0 8}$ & Mean A \\
\hline GBI1 & 0.100 & 0.570 & 0.830 & 1.290 & 1.170 & 1.033 & 1.000 & 0.95 & 0.900 & 0.850 & $\mathbf{0 . 8 7 0}$ \\
\hline GBI2 & 0.100 & 0.40 & 0.770 & 1.200 & 1.100 & 0.943 & 0.923 & 0.907 & 0.860 & 0.820 & 0.800 \\
\hline GYI10 & 0.130 & 0.280 & 0.690 & 1.333 & 1.130 & 1.067 & 1.067 & 1.050 & 0.950 & 0.900 & 0.860 \\
\hline GPI3 & 0.170 & 0.310 & 0.517 & 1.007 & 0.960 & 0.927 & 0.897 & 0.877 & 0.830 & 0.800 & 0.730 \\
\hline GYI5 & 0.100 & 0.470 & 0.760 & 1.267 & 1.100 & 1.017 & 1.013 & 0.960 & 0.920 & 0.880 & 0.850 \\
\hline GYI11 & 0.100 & 0.350 & 0.737 & 1.267 & 1.170 & 1.000 & 0.970 & 0.927 & 0.880 & 0.820 & 0.820 \\
\hline GYI4 & 0.170 & 0.310 & 0.720 & 1.267 & 1.170 & 1.017 & 0.993 & 0.923 & 0.880 & 0.830 & 0.830 \\
\hline GBI3 & 0.170 & 0.640 & 0.937 & 1.333 & 1.230 & 1.133 & 1.067 & 1.020 & 0.950 & 0.890 & $\mathbf{0 . 9 4 0}$ \\
\hline GPI2 & 0.130 & 0.250 & 0.667 & 1.300 & 1.230 & 1.133 & 1.100 & 1.067 & 0.960 & 0.900 & $\mathbf{0 . 8 8 0}$ \\
\hline GPI5 & 0.170 & 0.230 & 0.723 & 1.133 & 1.050 & 0.95 & 0.937 & 0.900 & 0.860 & 0.830 & 0.780 \\
\hline GPI6 & 0.130 & 0.320 & 0.773 & 1.233 & 1.090 & 1.067 & 1.033 & 0.973 & 0.910 & 0.860 & 0.840 \\
\hline Mean B & 0.130 & 0.370 & 0.738 & 1.249 & 1.130 & 1.026 & 1.000 & 0.959 & 0.900 & 0.850 & \\
\hline
\end{tabular}

\begin{tabular}{|c|c|c|c|}
\hline Factors & C.D. & SE(d) & SE(m) \\
\hline Factor(A) & 0.032 & 0.016 & 0.012 \\
\hline Factor(B) & 0.031 & 0.016 & 0.011 \\
\hline Factor(A X B) & 0.102 & 0.051 & 0.036 \\
\hline
\end{tabular}

Table.3 Statistical analysis of effect of time (hrs) on gold nanoparticles synthesis at $560 \mathrm{~nm}$ O.D

\begin{tabular}{|c|c|c|c|c|c|c|c|c|c|c|c|}
$\begin{array}{r}\text { Time in } \\
\text { (hrs) } \\
\text { Isolates }\end{array}$ & $\mathbf{0}$ & $\mathbf{1 2}$ & $\mathbf{2 4}$ & $\mathbf{3 6}$ & $\mathbf{4 8}$ & $\mathbf{6 0}$ & $\mathbf{7 2}$ & $\mathbf{8 4}$ & $\mathbf{9 6}$ & $\mathbf{1 0 8}$ & Mean A \\
\hline GBI1 & 0.200 & 0.570 & 0.840 & 1.330 & 1.230 & 1.070 & 1.000 & 0.950 & 0.910 & 0.860 & $\mathbf{0 . 9 0 0}$ \\
\hline GBI2 & 0.230 & 0.410 & 0.780 & 1.200 & 1.100 & 0.990 & 0.930 & 0.910 & 0.860 & 0.830 & 0.820 \\
\hline GYI10 & 0.200 & 0.290 & 0.700 & 1.330 & 1.200 & 1.100 & 1.100 & 1.050 & 0.950 & 0.910 & 0.870 \\
\hline GPI3 & 0.270 & 0.320 & 0.520 & 1.010 & 0.990 & 0.940 & 0.910 & 0.880 & 0.840 & 0.800 & 0.750 \\
\hline GYI5 & 0.200 & 0.470 & 0.760 & 1.300 & 1.170 & 1.050 & 1.020 & 0.970 & 0.920 & 0.890 & 0.870 \\
\hline GYI11 & 0.200 & 0.360 & 0.740 & 1.270 & 1.200 & 1.000 & 0.970 & 0.930 & 0.890 & 0.840 & 0.840 \\
\hline GYI4 & 0.270 & 0.320 & 0.720 & 1.270 & 1.230 & 1.030 & 0.990 & 0.890 & 0.880 & 0.830 & 0.840 \\
\hline GBI3 & 0.270 & 0.640 & 0.940 & 1.330 & 1.270 & 1.170 & 1.070 & 1.020 & 0.960 & 0.910 & $\mathbf{0 . 9 6 0}$ \\
\hline GPI2 & 0.230 & 0.250 & 0.680 & 1.300 & 1.230 & 1.100 & 1.030 & 1.000 & 0.960 & 0.910 & $\mathbf{0 . 8 8 0}$ \\
\hline GPI5 & 0.230 & 0.240 & 0.730 & 1.170 & 1.090 & 0.990 & 0.920 & 0.890 & 0.870 & 0.830 & 0.800 \\
\hline GPI6 & 0.200 & 0.330 & 0.780 & 1.230 & 1.130 & 1.100 & 1.030 & 0.980 & 0.920 & 0.870 & 0.860 \\
\hline Mean B & 0.230 & 0.380 & 0.750 & 1.250 & 1.170 & 1.050 & 1.000 & 0.950 & 0.910 & 0.860 & \\
\hline
\end{tabular}




\begin{tabular}{|c|c|c|c|}
\hline Factors & C.D. & SE(d) & SE(m) \\
\hline Factor(A) & 0.035 & 0.017 & 0.012 \\
\hline Factor(B) & 0.032 & 0.017 & 0.011 \\
\hline Factor(A X B) & 0.102 & 0.051 & 0.036 \\
\hline
\end{tabular}
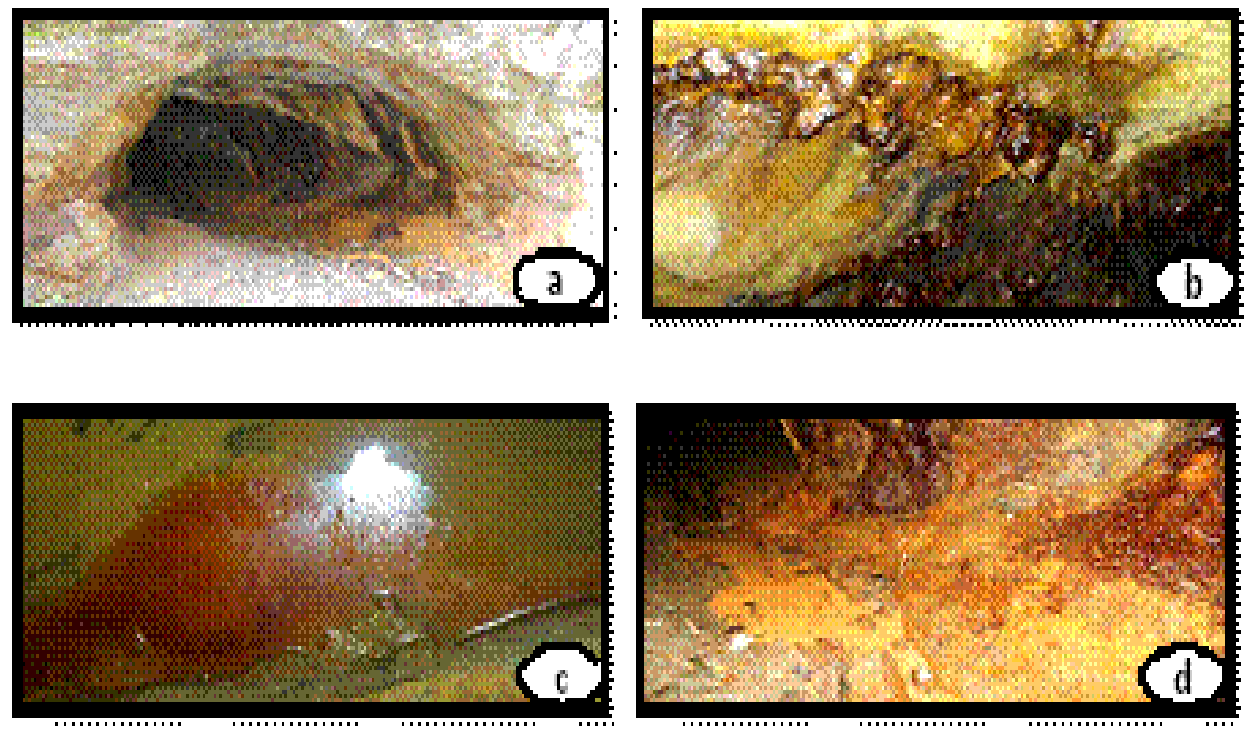

Figure 1: Sample collection sites: Khaltnnala gold mine from where sample were collected, representing (a) pebble (b) roof toppirg (c) bioflm (d) yelbw soil

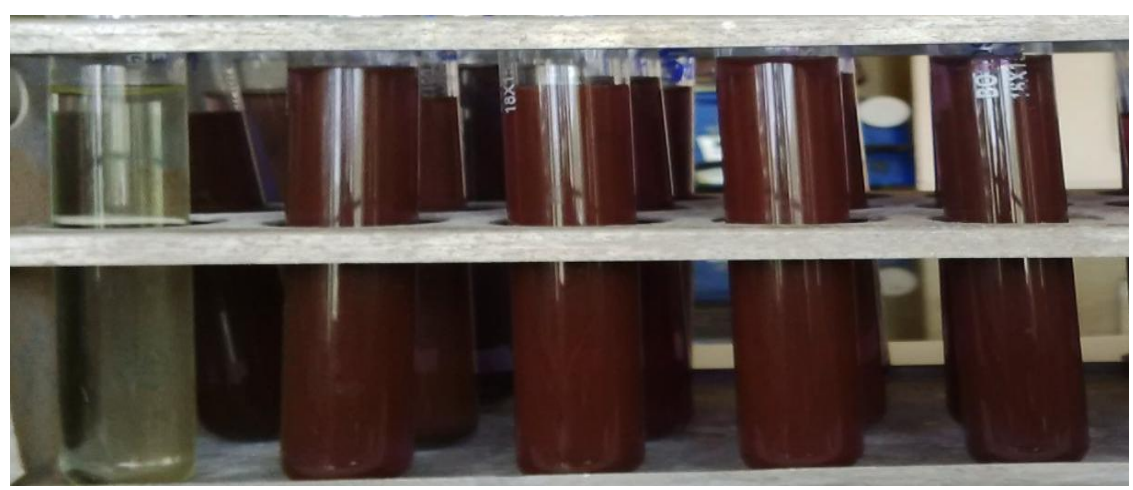

Figure:2 Biosynthesized gold nanoparticles in a colloidal dispersion using the supernatant of Bacillus licheniformis GPI-2 


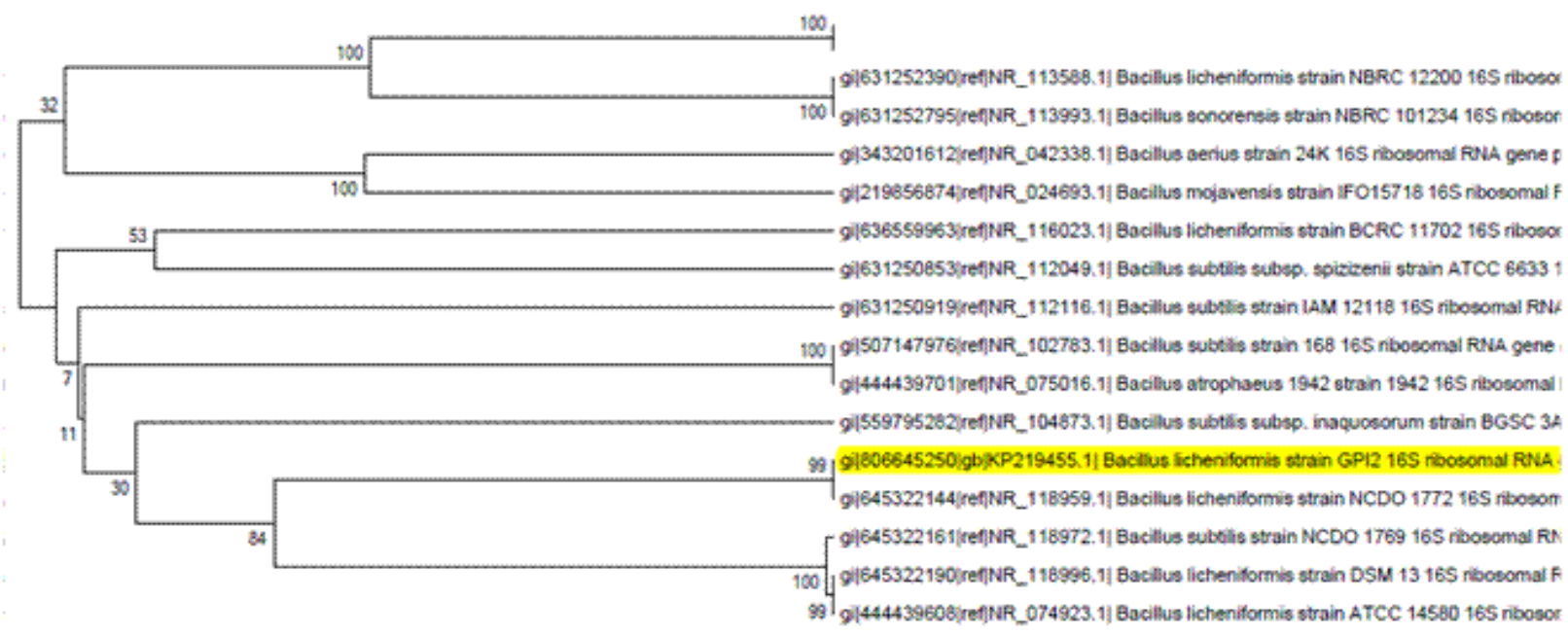

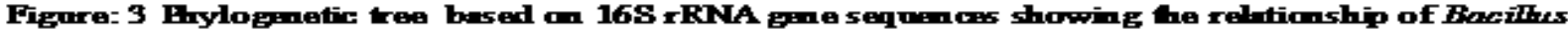
Iieksonfowis GH-2

Fig.4a, b UV-Vis absorption spectra of gold nanoparticles after incubation of supernatant of Bacillus licheniformis GPI-2 with 1mM sodium chloride for time period (0-240 hrs) at $6.8 \mathrm{pH}$
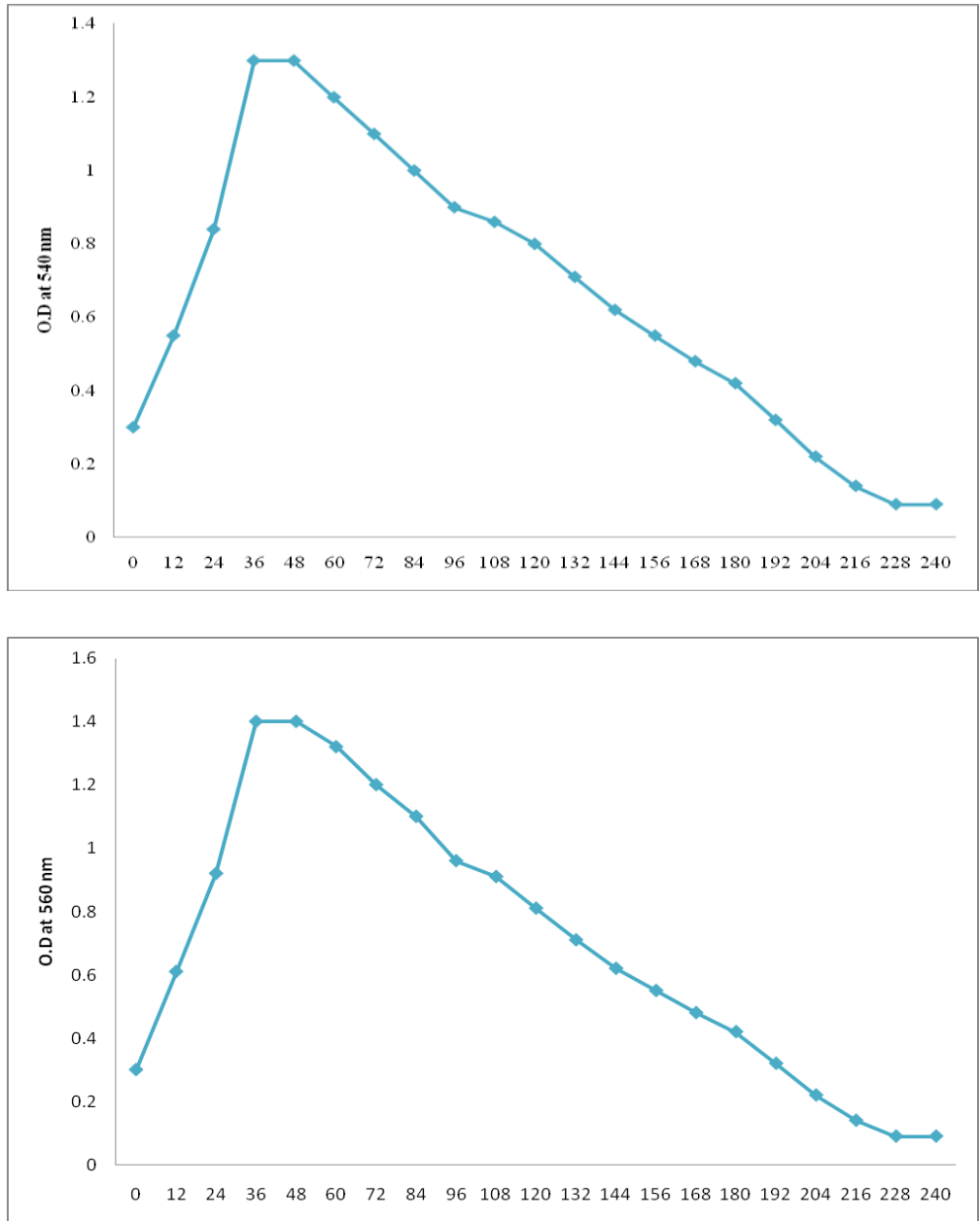


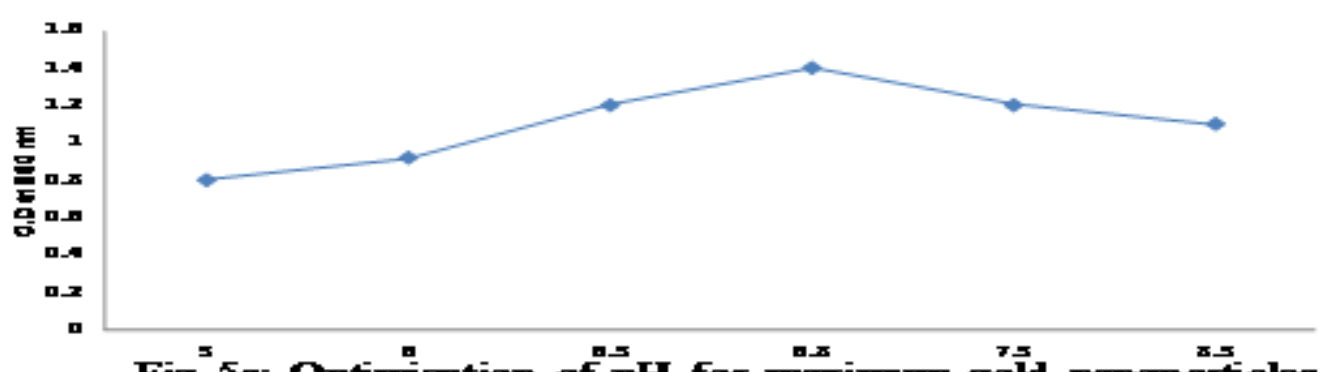

Fig 5 a Optimization of ${ }^{30}$ H for maximm gold namoparticles synthesis
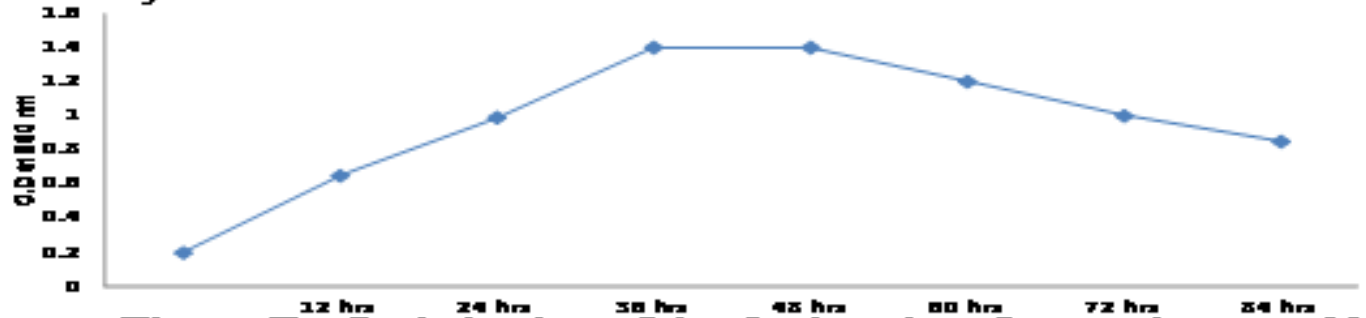

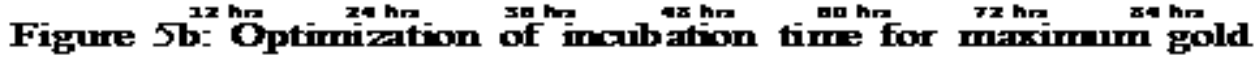
namoparticles synthesis

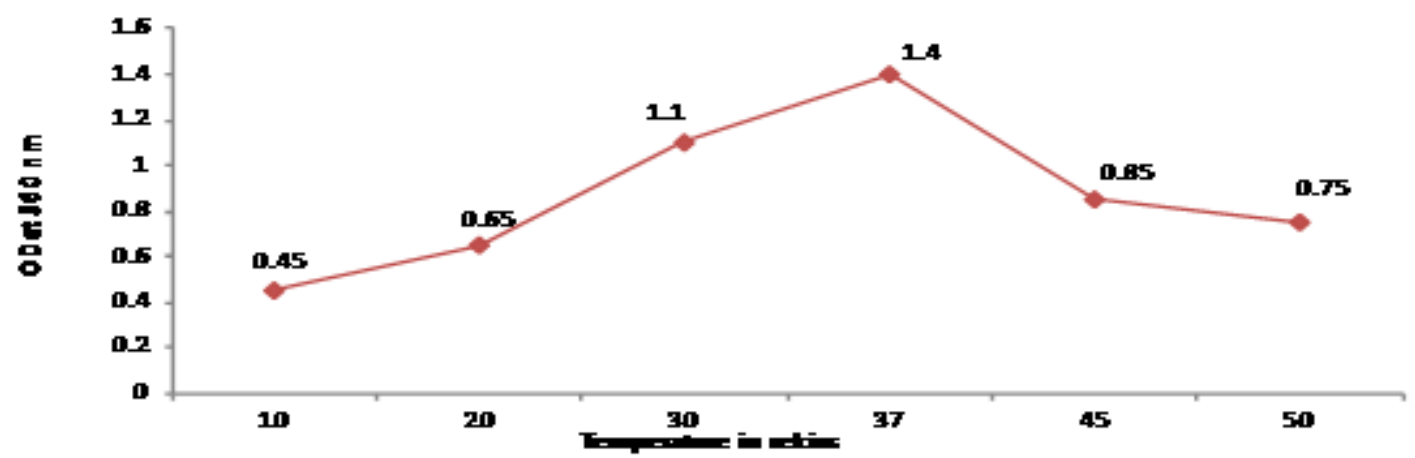

Figune 5c- Optimization of temperature for maximm gold namoparticles synthesis

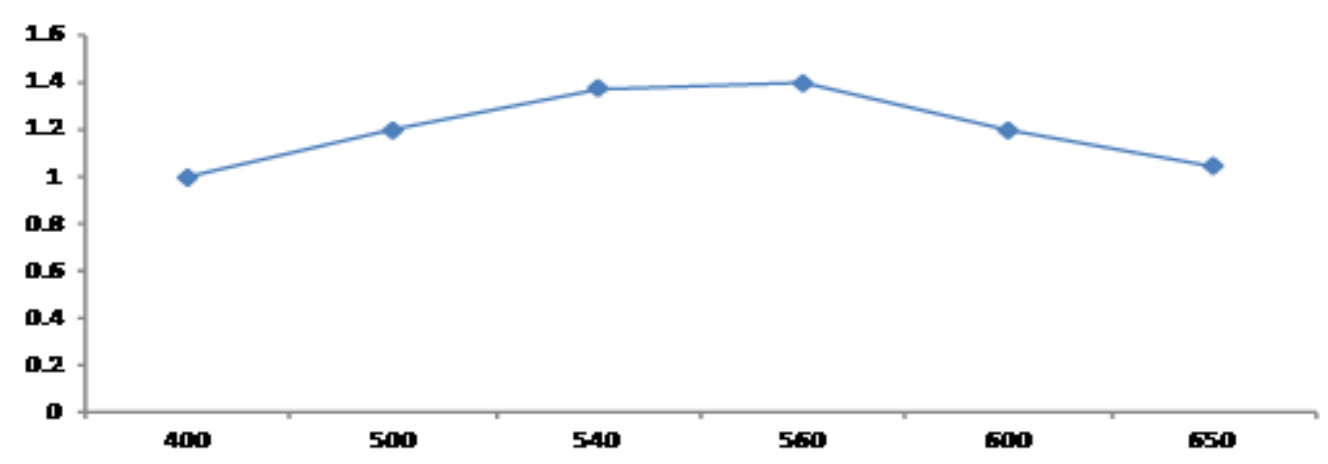

Fig 5d: Optimization of wavelength on gold namoparticles synthesis 


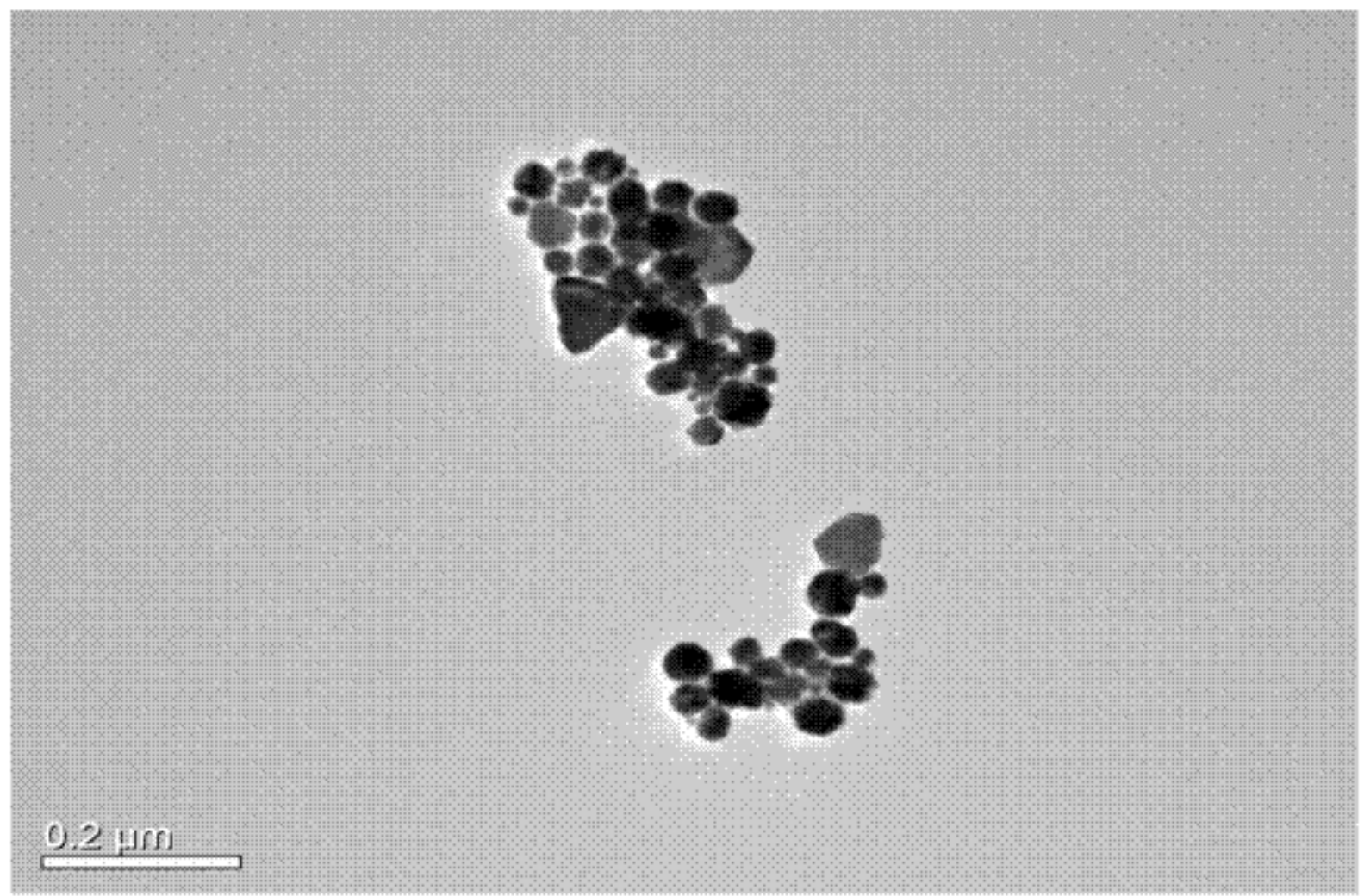

Figure 7a: Chactirization of gold namparticles hrough trasmission electron microscope showing the differitm ophology of goldnancpartides.

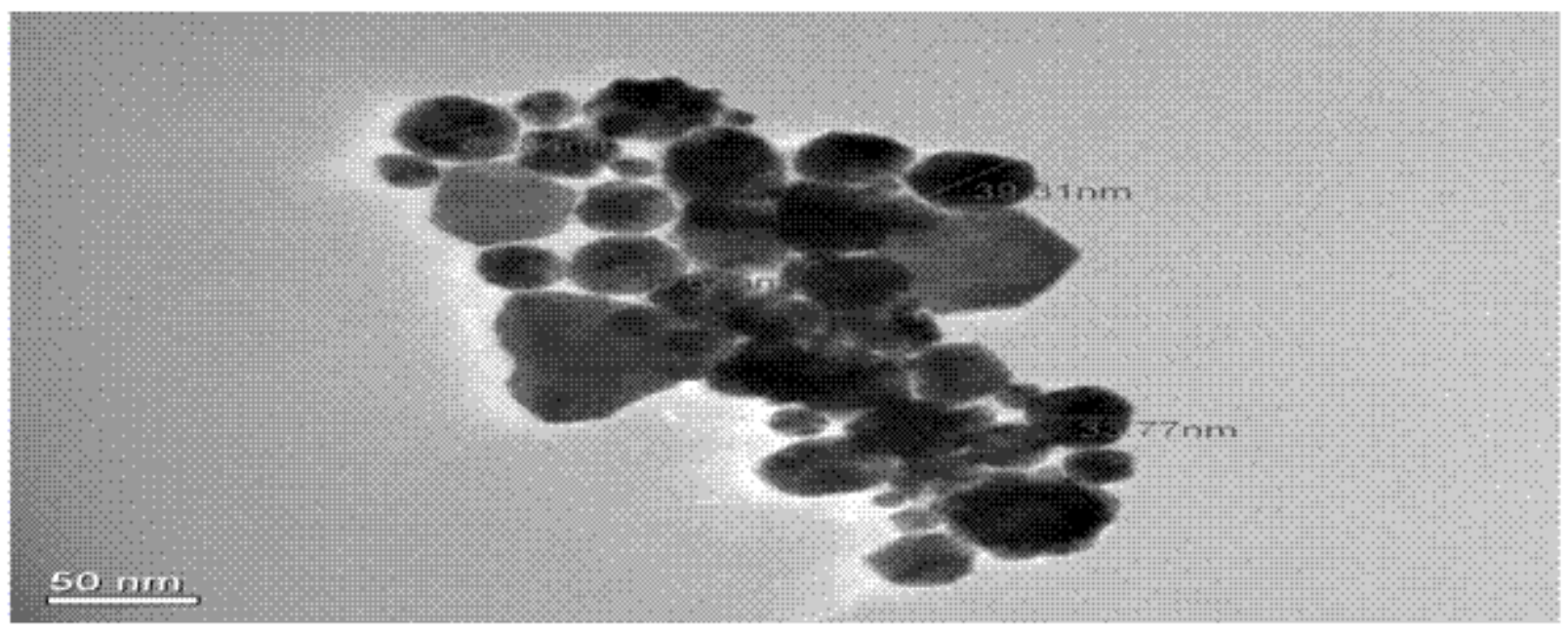

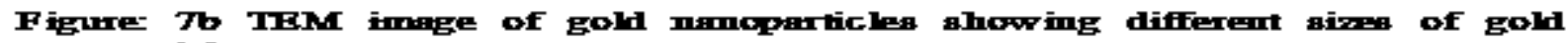
mamopanticles 
Fig.6 FTIR spectra recorded after 36 hrs of incubation by using supernatant of Bacillus licheniformis GPI-2 with gold chloride

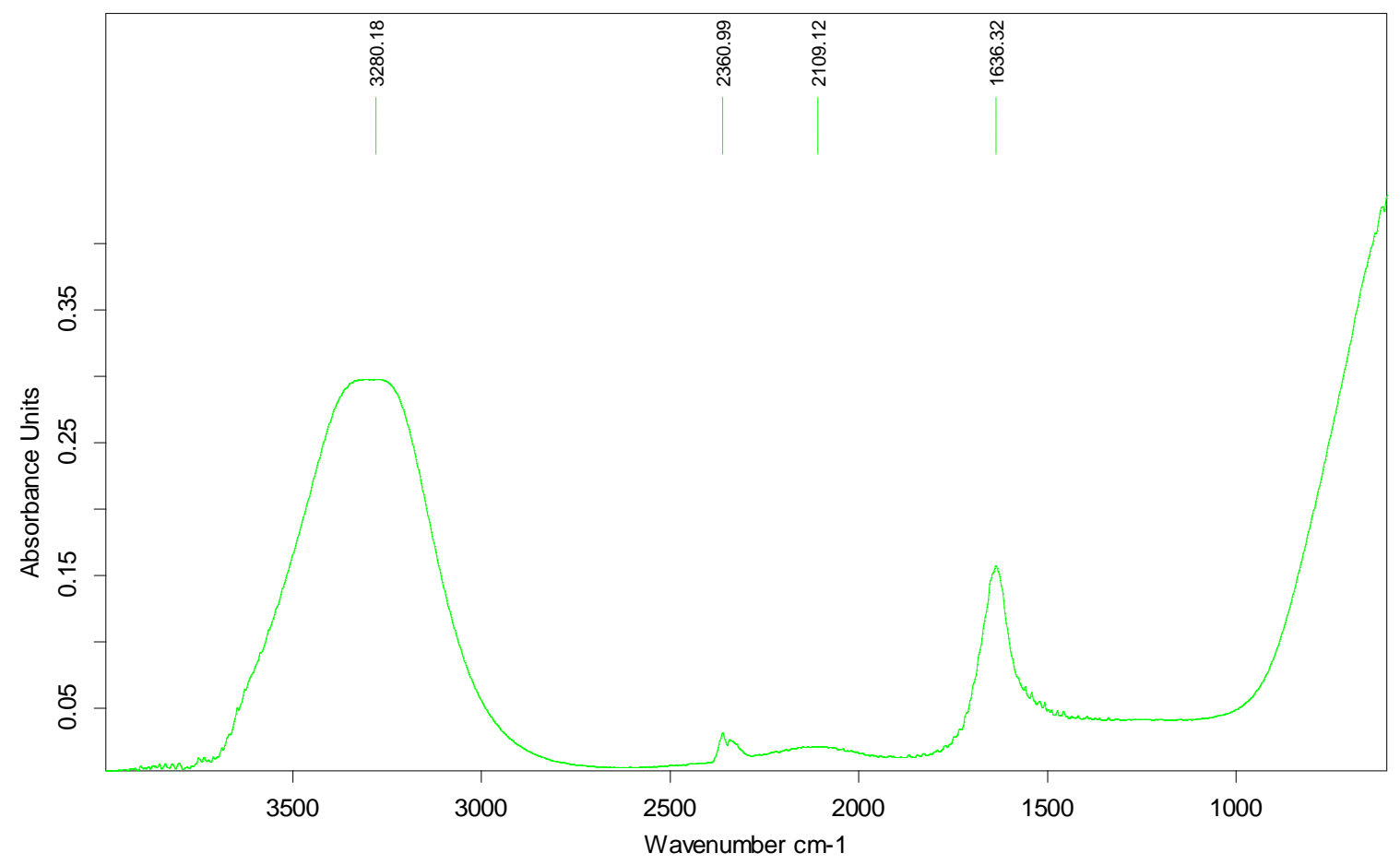

Map.1 Representing sites from where samples has been collected (Kasol, Vashist, Manikaran, Kalath)

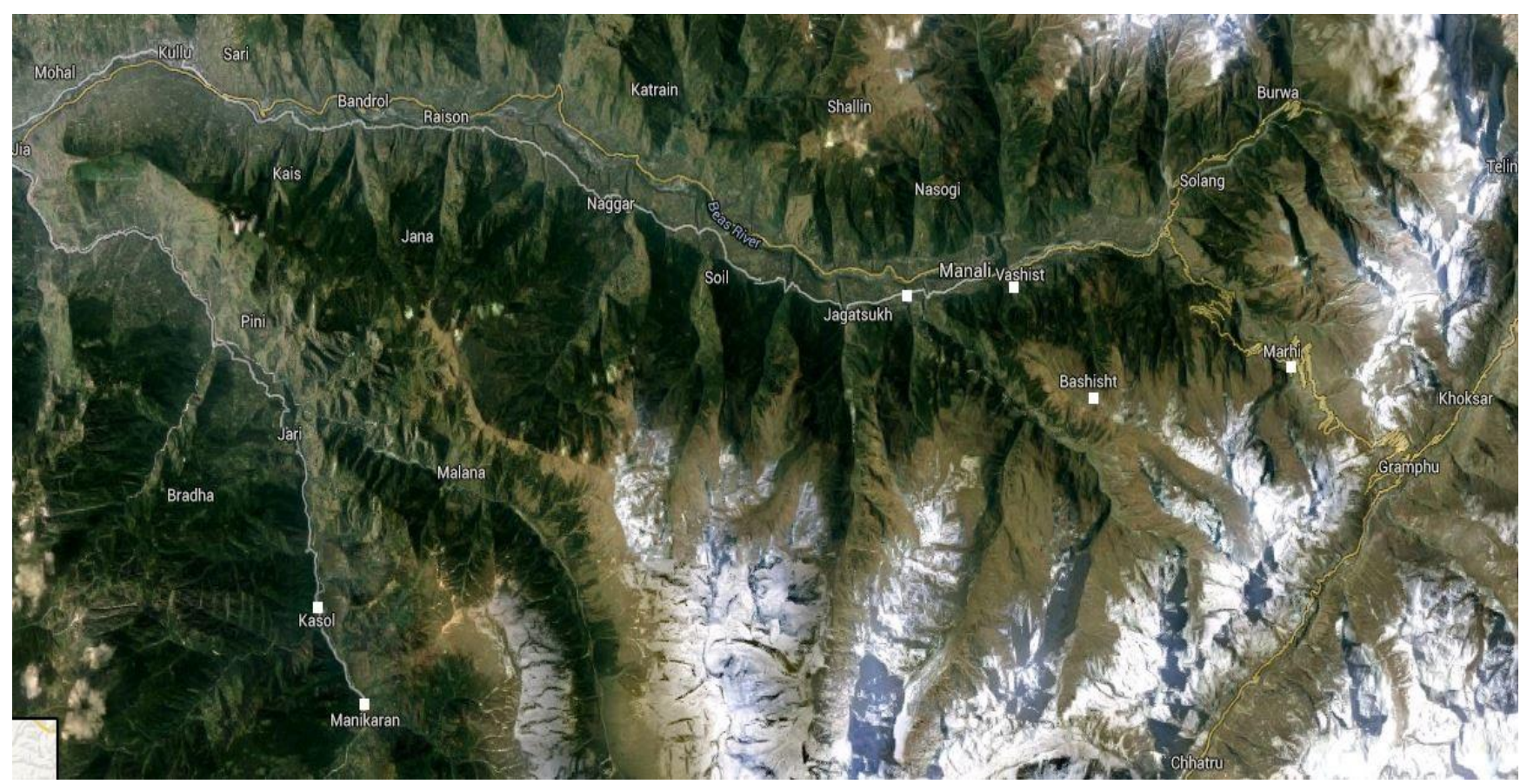


Amide 1 absorption is primarily determined by the backbone conformation and independent of the amino acid region, Its hydrophilic or hydrophobic properties and charge. Average frequency of the main components is about $1629 \mathrm{~cm}^{-1}$. Arginine amino acid role was found at $1636 \mathrm{~cm}^{-1}$ in gold nanoparticles synthesis through results of FTIR. The two TEM images (Figure 7a and 7b) clearly showed discrete gold nanoparticles in the size range of 40 to $45 \mathrm{~nm}$ which were mostly triangular, irregular and hexagonal indicating that it was possible to synthesize gold particles of nanodimensions with satisfactory level of monodispersity.

The present work help us develop green route of simple and economic synthesis of gold nanoparticles of $40-45 \mathrm{~nm}$. The particles synthesized by Bacillus licheniformis GPI-2 were characterized by UV vis spectrophotometer and confirmed by TEM. Extracellular, spherical, monodispersed /small clusters of gold nanoparticles were successfully produced, which were confirmed by Transmission electron. Proteins that serve as biomolecules responsible for the reduction process were confirmed by Fourier Transform Infrared Spectroscopy (FTIR).

The biological function of the gold nanoparticles shown great promise to deliver industry demands, moreover, this process could be easily scaled up for the industrial applications to increase the yield of the nanoparticles significantly, which undoubtedly would establish its commercial viability. Our research was focused on identification and exploration of gold nanoparticles synthesizing bacteria.

\section{Competing interests}

The authors declare that they have no competing interests.

\section{Authors' contributions}

PS conceptualized and designed experiments and provided technical support and helped in drafting the manuscript. RKT conducted experiments, isolation of bacteria, morphological and molecular characterization, in vitro synthesis of gold nanoparticles and characterization using FTIR and TEM and helped in drafting the manuscript both author read and approved the final manuscript.

\section{Author information}

$\mathrm{RKT}$ is a $\mathrm{PhD}$ research scholar currently and member of six international and national science societies. PS is a professor of Biotechnology with 30 years research experience and has published research papers in the journals of international and national repute.

\section{Acknowledgement}

The authors thank to Dr. C Raman Suri and Dr. Manoj Raje for the technical guidance and Dr. CK Shirkot and Dr. Garish Sahani for their cooperation.

\section{References}

Alonso-Saez, L., Gasol, J.M. 2007. Seasonal Variations in the Contributions ofdifferent Bacterial Groups to the Uptake of Low-Molecular-Weight Compounds in Northwestern Mediterranean Coastal Waters. Appl. Environ. Microbiol., 73: 3528-3535.

Amanda, J.H., Lei, C., William, L.K., Richard, P.V.D. 2005. Detection of a biomarker for Alzheimer's disease from synthetic and clinical samples using a nanoscale optical biosensor. J. Am. Chem. Soc., 127: 2264-71.

Atlas, R.M., Bartha, R. 1993. Microbial 
Ecology: Fundamentals and Applications.

Birla, S.S., Tiwari, V.V., Gade, A.K., Ingle, A.P., Yadav, A.P., Rai, M.K. 2009. Fabrication of silver nanoparticles by Phoma glomerata and its combined effect against Escherichia coli Pseudomonas aeruginosa and Staphylococcus aureus. Lett. Appl. Microbiol., 48: 173-179.

Brodie, E.L., DeSantis, T.Z., Parker, J.P.M., Zubietta, I.X., Piceno, Y.M., et al., 2007. Urban aerosols harbor diverse and dynamic bacterial populations. PNAS, 104: 299-304.

Cail, W., Gao, T., Hong, H., Sun, J. 2008. Applications of gold nanoparticles in cancer nanotechnology. Nanotechnol. Sci. Appl., 1: 17-32.

Duran, N., Marcato, P.D., Alves, O.L., DeSouza, G., Esposito, E. 2005. Mechanistic aspects of biosynthesis of silver nanoparticles by several Fusarium oxysporum strains. J. Nanobiotechnol., 3: $1-8$.

Fang, M., Kremer, R.J., Motavalli, P.P., Davis, G. 2005. Bacterial Diversity inRhizospheres of Nontransgenic and Transgenic Corn. Appl. Environ. Microbiol., 71: 4132-4136.

Fierer, N., Breitbart, M., Nulton, J., Salamon, P., Lozupone, C., et al. 2007. Metagenomic and Small-Subunit rRNA Analyses Reveal the Genetic Diversity of Bacteria, Archaea, Fungi, and Viruses in Soil. Appl. Environ. Microbiol., 73: 7059-7066.

Frias-Lopez, J., Shi, Y., Tyson, G.W., Coleman, M.L., Schuster, S.C., et al. 2008. Microbial community gene expression in ocean surface waters. Proc. Natl. Acad. Sci. U S A, 105: 3805-3810.

Gade, A.K., Bonde, P., Ingle, A.P., Marcato, P.D., Duran, N. and Rai, M.K. 2008. Exploitation of Aspergillus niger for synthesis of silver nanoparticles. $J$. Biobased Mater Bioenergy, 2: 243-247.

Gade, A.K., Bonde, P., Ingle, A.P., Marcato, P.D., Duran, N., Rai, M.K. 2008. Exploitation of Aspergillus niger for synthesis of silver nanoparticles. $J$. Biobased Mater Bioenergy, 2: 243-247.

Gericke, M. and Pinches, A. 2006. Microbial production of gold nanoparticles. Gold Bull., 39(1): 22-28

Ghosh, P., Han, G., De, M., Kim, C.K., Rotello, V.M. 2008. Gold nanoparticles in delivery applications. Adv. Drug Deliv. Rev., 60: 1307-1315.

Holt, J.G., Krieg, R.N., Sneath, P.H.A., Staley, J.T., Williams, S.T. 1994. Bergey's Manual of Determinative Bacteriology.9th edition. Williams and Wilkins, Baltimore.

Kaithresan, K., Manivanan, S., Nabeel, M.A. and Dhivya, B. 2009. Studies on silver nanoparticles synthesized by a marine fungus, Penicillium fellutanum isolated from coastel mangrove sediment. Colloides surf. B Biointerfaces, 71: 133.

Khan, A.K,. Rashid, R., Murtaza, G., Zahra, A. 2014. Gold Nanoparticles: Synthesis and Applications in Drug Delivery. Trop. J. Pharm. Res., 13(7): 1169.

Kumar, A.S., Ansary, A.A., Ahmad, A., Khan, M.I. 2007. Extracellular biosynthesis of CdSe quantum dots by the fungus, Fusarium Oxysporum. $J$. Biomed. Nanotechnol., 3: 190-194.

Kumar, S.A,. Abyaneh, M.K., Gosavi, S.W., Kulkarni, S.K., Pasricha, R., Ahmad, A., Khan, M.I. 2007. Citrate reductasemediated synthesis of silver nanoparticles from $\mathrm{AgNO}_{3}$. Biotechnol. Lett., 29: 439-445.

Lengke, M.F., Fleet, M.E., Southam, G. 2006. Morphology of gold nanoparticles synthesized by filaments cynobacteria from gold (III) chloride complexes. Langmuir, 22(6): 2780-2787.

Michalke, K,. Schmidt, A., Huber, B., Meyer, 
J., Sulkowski, M., et al., 2008. Role of Intestinal Microbiota in Transformation of Bismuth and Other Metals and Metalloids into Volatile Methyl and Hydride Derivatives in Humans and Mice. Appl. Environ. Microbiol., 74: 3069-3075.

Mohammed, F.A., Balaji, K., Girilal, M., Kalaichelvan, P.T., Venkatesan, R. 2009. Mycobased synthesis of silver nanoparticles and their incorporation into sodium alginate films for vegetable and fruit preservation. J. Agric. Food Chem., 57: 6246-52.

Mohammed, F.A., Balaji, K., Girilal, M., Yadav, R., Kalaichelvan, P.T., Venkatesan, R. 2010. Biogenic synthesis of silver nanoparticles and their synergistic effect with antibiotics: a study against Gram-positive and Gram-negative bacteria. Nanomed., 6: 103-9.

Mohammed, F.A., Tiwary, C.S., Kalaichelvan, P.T., Venkatesan, R. 2009. Blue orange light emission from biogenic synthesized silver nanoparticles using Trichoderma viride. Colloid Surface B: Biointerface, 75: 175-8.

Mukherjee, P., Bhattacharya, R., Wang, P., Wang, L., Basu, S., Nagy, J.A., Atala, A., Mukhopadhyay, D., Soker, S. 2005. Antiangiogenic Properties of Gold Nanoparticles. Clin. Cancer Res., 11: 3530-3534.

Mukherjee, P., Roy, M., Mandal, B.P., Dey, G.K., Mukherjee, P.K., Ghatak, J., Tyagi, A.K., Kale, S.P. 2008. Green synthesis of highly stabilized nanocrystalline silver particles by a non-pathogenic and agriculturally important fungus T. asperellum. Nanotechnol., 19: 103-110

Nair, B., Pradeep, T. 2002. Coalescence of nanoclusters and formation of submicron crystallites assisted by
Lactobacillus strains. Cryst. Growth Design, 2: 293-298.

Navarro, M., Pérez, H., Sánchez-Delgado, R.A. 1997. Toward a novel metal-based chemotherapy against tropical diseases. 3. Synthesis and antimalarial activity in vitro and in vivo of the new goldchloroquine complex [Au (PPh3)(CQ)] PF6. J. Med. Chem., 40: 1937-1939.

Rai, M., Yadav, A., Bridge, P. and Gade, A. 2009. Myconanotechnology: a new and emerging science. In: Rai MK, Bridge PD (eds) Appl. Mycol., vol 14. CAB International: New York: pp 258-267.

Rai, M., Yadav, A., Gade, A. 2008. Current trends in phytosynthesis of metal nanoparticles. Crit. Rev. Biotechnol., 28(4): 277-284.

Redwood City. 1991. The Benjamin/ Cummings Publishing Company, Inc.

Riddin, T.L., Gericke, M., Whiteley, C.G. 2006. Analysis of the inter- and extracellular formation of platinum nanoparticles by Fusarium oxysporum f.sp. Lycopersici using surface response methodology. Nanotechnol., 14: 34823489.

Roesch, L.F.W., Fulthorpe, R.R., Riva, A., Casella, G., Hadwin, A.K.M., et al. 2007. Pyrosequencing enumerates and contrasts soil microbial diversity. ISME J., 1: 283-290.

Schloss, P.D., Handelsman, J. 2006. Toward a Census of Bacteria in Soil. PLoS Computational Biol., 2: e92.

Sharma, N., Pinnaka, A.K., Raje, M.A., Bhattacharyya, S.M. and Choudhury, A.R. 2012. Exploitation of marine bacteria for production of gold nanoparticles. Microbial Cell Factories, 11: 86.

Sharma, V.K., Yngard, R.A., Lin, Y. 2009. Silver nanoparticles: green synthesis and their antimicrobial activities. $A d v$. Colloid Interface Sci., 145: 83-96.

Shomura ,Y. 2011. In Advances in Composite 
Materials for Medicine and Nanotechnology: Composite Material Stent Comprising Metallic and Nonmetallic Materials. Edited by Attaf B. Croatia: InTech; 59-74.

Sintubin, L., Windt, W.E., Dick, J., Mast, J., Ha, D.V., Verstarete, W., Boon, N. 2009. Lactic acid bacteria as reducing and capping agent for the fast and efficient production of silver nanoparticles. Appl. Microbiol. Biotechnol., 87: 741-749.

Sogin, M.L., Morrison, H.G., Huber, J.A., Welch, D.M., Huse, S.M., et al. 2006. Microbial diversity in the deep sea and the underexplored "rare biosphere". Proceedings of the National Academy of Sciences, 103: 12115-12120.

Stevens, H., Ulloa, O. 2008. Bacterial diversity in the oxygen minimum zone of the eastern tropical South Pacific. Environ. Microbiol., 10: 1244-1259.

Tamura, K., Peterson, D., Peterson, N., Stecher, .G, Nei, M., Kumar, S. 2011. MEGA5: molecular evolutionary genetics analysis using maximum likelihood, evolutionary distance, and maximum parsimony methods. Mol. Biol. Evol., 28: 2731-2739.

Tsai, C.Y., Shiau, A.L., Chen, S.Y., Chen, Y.H., Cheng, P.C., Chang, M.Y., Chen, D.H. 2007. Amelioration of collageninduced arthritis in rats by nanogold. Arthritis and rheumatism, 56: 544-554

Whitman, W.B., Coleman, D.C., Wiebe, W.J. 1998. Prokaryotes: the unseen majority. Proc. Natl. Acad. Sci. U S A, 95: 65786583.

\section{How to cite this article:}

Rajni Kant Thakur, Poonam Shirkot and Ambika Verma. 2017. Exploration of Microbial Diversity of Himalaya Region for Gold Nanoparticles Synthesizing Bacteria. Int.J.Curr.Microbiol.App.Sci. 6(8): 2191-2210. doi: https://doi.org/10.20546/ijcmas.2017.608.259 